\title{
The effect of sago pith waste granule compost and inorganic fertilizer on soil physical characteristics and corn (Zea mays L.) production in Inceptisol
}

\author{
Maimuna La Habi ${ }^{1}$, Budi Prasetya ${ }^{2}$, Sugeng Prijono ${ }^{2}$, Zaenal Kusuma ${ }^{2}$, \\ ${ }^{l}$ (Department of Agriculture, Brawijaya University, Jl. Veteran Malang 65145 and Department of Agriculture, \\ Pattimura University, Jln. Ir.M.Putuhena, Poka-Ambon, Indonesia \\ ${ }^{2}$ (Department of Agriculture, Brawijaya University, Jl. Veteran Malang 65145, Indonesia)
}

\begin{abstract}
The study aimed to determine the effect of sago pith waste granule compost and inorganic fertilizers on soil physical characteristics and the results of corn in Inceptisol. The research design used in this study was a randomized block design with three replications. Treatment consisted of: no fertilizer (KGES1), with granule $8 t \mathrm{ha}^{-1}$ compost (KGES2), inorganic fertilizer (Urea, SP - 36, and KCl), recommended dosage (KGES3), inorganic fertilizer + granule 8 t ha compost $($ KGES4), $1 / 2 x$ dose of inorganic fertilizer + compost granule $(8 t$ $\left.h^{-1}\right)$ (KGES5) , 2 doses of inorganic fertilizer + granule $8 t h a^{-1}$ compost (KGES6), $1 / 2 x$ dose of inorganic fertilizer $+12 t \mathrm{ha}^{-1}$ granule compost (KGES7) and 2 times the dose of inorganic fertilizer $+4 t$ ha compost (KGES8). The results showed that sago pith waste granule compost and inorganic fertilizers significantly affect the physical characteristics of the soil that is categorized into heavy volume of soil $\left(0.80 \mathrm{~g} \mathrm{~cm}^{-3}\right)$, soil particle density $\left(2.30 \mathrm{~g} \mathrm{~cm}^{-3}\right)$, soil porosity $(7.77 \%)$, fast drainage pore $(23: 54 \%)$, slow drainage pore $(8.83 \%)$, available water pore (11.62\%), and unavailable water pore (11:31). On the other hand, the plant growth (plant height) and dry shelled corn grain results amounted to $249.17 \mathrm{~cm}$ and 7.85 tones $\mathrm{ha}^{-1}$. The combination of sago pith waste granule compost and inorganic fertilizer may improve the results of 30-47 \% better compared to inorganic fertilizer or granule compost alone. Excessive inorganic fertilizer did not show the significant increase of dry shelled corn seeds productions. Based on these results, the reduction of a half dose of inorganic fertilizer combined with $12 \mathrm{th} \mathrm{h}^{-1}$ granule compost yielded of dry shelled corn grain of the highest $\left(7.85 \mathrm{th} \mathrm{h}^{-1}\right)$ or in percentage the increase of the results of $32 \%$ of inorganic fertilizer application.
\end{abstract}

Keywords: Sago pith waste granular compost, phosphorous fertilizer, sustainable agriculture

\section{INTRODUCTION}

The increasing population lead to the limited number of fertile agricultural lands. These lands has been converted to residential area to meet the housing needs of the recent vast growth of human population [1]. Recent agricultural development is facing serious problems on land availability. In Indonesia, the marginal lands which are dominated by Inceptisol soil were abundant. This soil types is potential for future agricultural development [2]. Inceptisol is the dominant soil types in the Maluku, reaching up to $47.71 \%$ of the total land in the Maluku and it has considerable potential for agriculture area [3]. The Inceptisol in Indonesia have some basic characteristics, namely 1) nutrient status varies from low to high; 2) soil $\mathrm{pH}$ from acid - neutral; 3) levels of organic material low to moderate; 4) $\mathrm{N}$ and $\mathrm{P}$ content was low to high; 5) $\mathrm{K}$ is very low - moderate, and 6) CEC was low to high [4]. The provision of organic materials is one of solution efforts to improve soil physical and chemical characteristics that the acid soils and marginal land become productive soils.

Organic material is needed for the growth of plants. The addition of organic materials from several sources such as manure, green manure, crop residues compost, domestic compost, and industrial residues compost may repair and improve the physical characteristics of the soil [5],[6],[7],[8],[9],[10]. Compost has the ability to supply nutrients needed for plant vigor growth, merismatic and physiological processes of plants development [11], improving soil health, organic Carbon status, and availability of N, P, K, and S in the soil [12]. The addition of organic material, however, should be considered the organic material types, the amount as well as size of the application [6], [13]. Scholars point out that that the cotton gin crushed compost (CCGC) may improve the physical characteristics as well as the biological components of the soil and may improve the results and quality of wheat production, while the sewage sludge (SS) turn down the biological status of soil as well as the wheat growth [6].

Sago is a plant in the family of Palmae with fairly large planting areas in Indonesia. There are estimating about 7,000,000 ha of sago planting area [14]. It is equal to approximately $51.3 \%$ of the total area of sago in the world [15]. Sago starch or flavor is the main result produced by the sago plant, while sago by products or wastes are generally used for animal feed, mushroom compost in the planting medium, or as raw material for plywood industry [14], [16]. Sago pith waste, in Maluku locally called "sago ela" can also play a 
role in improving the soil fertility. Sago pith waste is the potential source for organic material that has not been widely used. These material is abundance in eastern Indonesia, particularly in Maluku[17].

Corn (Zea mays L.) is one of the important agricultural commodities which is consumed as a source of food for humans as well as animal feeds [9],[18],[19],[20]. Recently, corn demand was increase significantly to meet numerous foods industrial materials. In Indonesia, the productivity of corn in 2004 was about $11,162,813$ tons, increasing by $2.93 \%$ or 276,371 tons compared to the productivity of 2003 (10,886,442 tons). In 2009, the national corn production was 17.63 million tons [21]. On the other data obtained by Maluku Provincial Agriculture Office for the harvested area, the average corn production from 2001 until 2005 overall have increased respectively 4,754 ha to 6,089 ha and $15.54 \mathrm{kw} \mathrm{ha}^{-1}$ to $23,42 \mathrm{kw} \mathrm{ha}^{-1}$, but for the City of Ambon was only 54 ha with an average production of $23.33 \mathrm{kw} \mathrm{ha}^{-1}$ In 2009, the total corn production in North Maluku was reached up to 13,990 tons [22]. From the statistical results above, it can be seen that the production center of the city of Ambon was the lowest as it was compared to other areas in Maluku region. Corn can be grown on both clay and argillaceous clay, has good drainage, $\mathrm{pH}$ between $5.0-8.0$, but corn is prone to salinity [23]. The production of corn needs to be improved. Fertilizers might play a role in balancing the soil conditions resulting in increased porosity, soil aerase, ground water and power supply to optimize the soil moisture at or below the permanent wilting point. This research aims to examine the effect of sago ela granule compost and inorganic fertilizer to repair some soil physical characteristics as well as the growth of corn plant growth in Inceptisol.

\section{METHODS}

The experiments were conducted in May 2012 at the Kepuharjo experimental farm, Brawijaya University and followed by laboratory analysis in Faculty of Agriculture Brawijaya University and BALITAN Bogor. This study used some tools and materials, namely granulator for making organic fertilizer granules, Inceptisol soil type, sago pith waste, manure, sugar, leaf of Leucaena leucocephala (Lam.) de Wit, culture solution of EM-4, Srikandi Kuning variety yellow corn, urea (46\% N), $\mathrm{KCl}(60 \% \mathrm{~K} 2 \mathrm{O})$, and SP-36 $\left(45 \% \mathrm{P}_{2} \mathrm{O}_{5}\right)$, pesticides (Furadan 3G).

The research design employed in this study was a randomized block design with three replications. Treatments consist of: no fertilizer (KGES1), with granule $8 \mathrm{t} \mathrm{ha}^{-1}$ compost (KGES2), inorganic fertilizer (Urea, SP - 36, and $\mathrm{KCl}$ ), recommended dosage (KGES3), inorganic fertilizer + granule $8 \mathrm{t}$ ha ${ }^{-}$compost ( KGES4 ), $1 / 2$ $\mathrm{x}$ dose of inorganic fertilizer + compost granule $\left(8 \mathrm{tha}^{-1}\right)(\mathrm{KGES} 5), 2$ doses of inorganic fertilizer + granule $8 \mathrm{t}$ $\mathrm{ha}^{-1}$ compost (KGES6), $1 / 2 \mathrm{x}$ dose of inorganic fertilizer $+12 \mathrm{tha}^{-1}$ granule compost (KGES7) and 2 times the dose of inorganic fertilizer $+4 \mathrm{t}$ ha compost (KGES8). Application of enriched sago pith waste granule compost performed twice: 50\% at planting and 50\% at 30 days after (HST). Fertilizer N, P and K were given three times, namely $50 \%$ at 10 days after planting, $30 \%$ at 30 days after planting and $20 \%$ at 40 days after planting.

Parameters being observed in this study were soil physical characteristics, growth and corn products. The physical characteristics of Inceptisol being observed include soil bulk density using the cylinder method, soil particle density using the pycnometer method, porosity using method (1 - (BI / BJ) x $100 \%)$, fast pore drainage (macro-pore) using the gravimetric method, slow pore drainage (meso-pore), available pore water (micro-pore). The growth and products of the plants being observed included plant height and dry shelled corn weight produced. The data were analyzed its diversity by using program GENSTAT $12^{\text {th }}$ for Windows. Analysis of variance (ANOVA) was according to the design and test patterns used are RGD, and significantly different if followed by a test of Duncan Multiple Range Test (DMRT) at 5\% level. Correlation and regression analysis were used to determine the closeness and the relationship between treatment and observed variables.

\section{Chemical Characteristics of Enriched Granule Fertilizer}

\section{RESULTS AND DISCUSSIONS}

Based on the results of basic analysis of nutrient quality of sago pith waste granule compost shows that the compost tends to slightly alkaline $\mathrm{pH}(\mathrm{pH} \mathrm{H} 2 \mathrm{O} 7.8$ and $\mathrm{pH} \mathrm{KCl} \mathrm{7.8).} \mathrm{This} \mathrm{suggests} \mathrm{that} \mathrm{the} \mathrm{application} \mathrm{of}$ compost made of sago pith waste may serve to increase the soil $\mathrm{pH}$ while on the other hand reduce adverse effects (decrease in soil $\mathrm{pH}$ ) due to inorganic fertilizer. The content of organic materials in the sago pith waste compost is relatively high up to $26.85 \%$. In terms of nutrition, the concentrations of nutrients of $\mathrm{N}, \mathrm{P}$, and $\mathrm{K}$ in compost made of sago pith waste are in a row of $1.56 \%, 1.03 \%$ and $0.69 \%$, with the water content of $12-15 \%$. Compared to the nutrient content of manure from cattle cows and chickens, the compost made of from sago pith waste has the higher content of $\mathrm{N}$ and $\mathrm{P}$, but the element $\mathrm{K}$ is lower than chicken manure and higher than cow one. The compost produced has $\mathrm{C} / \mathrm{N}$ ratio of 10 which means that the fertilizer is categorized into high quality and quickly decomposed much faster in terms of the supply of nutrients. Nutrient enrichment was conducted through the addition of NPK that might improve the content of N, P, and $\mathrm{K}$, respectively to $\mathrm{N}=2.43 \%, \mathrm{P}=$ $1.02 \%$, and $\mathrm{K}=0.87 \%$. 


\section{Preliminary Analysis}

The results of the preliminary analysis of the physical characteristics and chemical both Inceptisol soil before the experiment are presented in Table 1. Based on the results, it is shown that the Inceptisol in study site was the high soil acidity ( $\mathrm{pH}$ 5.5). The soil was dominated by clay fraction followed by dust and sand fractions. These can be classified into clay texture. The presence of clay texture which causes moderate porosity values were dominated by rapid drainage pore followed by successive pore water was not available, the available pore and pore water drainage were slow. This is because the soil is dominated by micro pores and as a result most of the water is difficult to penetrate soil.

Table 1 There are some physical and chemical characteristics of Inceptisol soil before the experiments

\begin{tabular}{lll}
\hline No. & Physical characteristics of the soil (depth of $0-20 \mathrm{~cm})$ & The result of analysis \\
\hline 1 & Texture : & \\
& - Sand (\%) & 16 \\
& - Dust (\%) & 40 \\
& - Clay (\%) & 44 \\
2 & Volume weight of soil $\left(\mathrm{g} \mathrm{cm}^{-3}\right)$ & 1.20 \\
& & \\
3 & Typical weight of soil $\left(\mathrm{g} \mathrm{cm}^{-3}\right)$ & 2.10 \\
& & \\
4 & Soil porosity (\% volume) & 4.43 \\
& & \\
5 & Pore spread: & 33,12 \\
& - Fast pore drainage (\% volume) & 5.49 \\
& - Slow pore drainage $(\%$ volume) & 8.35 \\
& - Available water pore $(\%$ volume) & 8.2 \\
& - Unavailable pore water $(\%$ volume & 0.46 \\
6 & pF 2 concentration of water $\left(\mathrm{cm}^{3} . \mathrm{cm}^{-3}\right)$ & 2.0 \\
7 & DMR $(\mathrm{cm})$ & 5.5 \\
8 & Soil Ph & \\
\hline
\end{tabular}

The soil conditions may inhibit the growth of crops grown planted on this soil. This happens due to impaired development of the roots of plants. Plant roots become shorter; it was bigger than usual, stiff like wire, easily broken, and the ends of the roots to swell. Thus the plant roots cannot absorb water and nutrients that will lead to plant water stress, even to nutrient deficiency [2]. According Radjagukguk (1983) the problems with Inceptisol were the high power of P fixation that causes elements immunity and Al toxicity [24]. In acidic mineral soils that have $\mathrm{pH}$ less than 5, soils containing oxides and hydroxides of $\mathrm{Al}$ and $\mathrm{Fe}$ (Seskuioksida) that have the ability to adsorb P highly. Thus the plant will experience a deficiency of P.

One of several alternatives that can be proposed to resolve such issues of soils is the use of organic materials such as compost [25]. Scholar that in order to overcome the problem of Ultisol containing high $\mathrm{Al}$ is through effective control of Al toxicity in plants through chelation of soil aluminum by utilizing compost and crop residues as a source of ligand. While in addition, the provision of organic materials such as granule compost may improve the physical characteristics of the soil [26]. One of the benefits is the increase of oxygen, carbon dioxide, nitrogen as well as water vapor through the soil microbes along with increasing soil moisture or porosity. The provision of organic material allows the formation of soil aggregates, which in turn will improve the circulation of air permeability and soil; plant roots may easily penetrate deeper and wider so that the plants grow sturdily and better due to its ability to absorb plant nutrients [27]. By providing compost that contains a lot of organic materials allows to provide an optimal environment for the life and activity of soil microorganisms as well as improve the soil physical characteristic such as soil aggregation, soil bulk density, soil particle density, soil porosity and other aspects. The addition of compost to the soil may result in the decrease in soil bulk density, where it is a positive impact on the increase in porosity of the soil as well as the soil aggregation [28], [29].

The results of sago pith waste granule compost analysis showed that sago pith waste granule ela compost has organic-C and high total $\mathrm{N}$, respectively (30.16\%) and (2.43\%). Based on analysis of the expected use of compost as sago pith waste granules compost treatments was it may improve the soil aggregation that might affect on the soil physical characteristics of Inceptisols. The results of the analysis of variance of the parameters Inceptisol soil on physical characteristics of the soil and the product of corn can be seen in Table 2 . 
Table 2 The effects of treatment dose sago pith waste granule compost and phosphate fertilizer on physical characteristics Inceptisol, and production of corn

\begin{tabular}{llllllll}
\hline Treatments & $\begin{array}{l}\text { Bulk } \\
\text { Density } \\
\left(\mathrm{g} \mathrm{cm}^{-3}\right)\end{array}$ & $\begin{array}{l}\text { Particle } \\
\text { density } \\
\left(\mathrm{g} \mathrm{cm}^{-3}\right)\end{array}$ & $\begin{array}{l}\text { Porosity } \\
(\%)\end{array}$ & $\begin{array}{l}\text { Macropore } \\
(\%)\end{array}$ & $\begin{array}{l}\text { Mesopore } \\
(\%)\end{array}$ & $\begin{array}{l}\text { Micropore } \\
(\%)\end{array}$ & $\begin{array}{l}\text { Dry weight yield } \\
\left.(\text { ton ha })^{-1}\right)\end{array}$ \\
\hline \hline KGES1 & $1.20 \mathrm{a}$ & $2.10 \mathrm{f}$ & $4.43 \mathrm{~g}$ & $33.12 \mathrm{a}$ & $5.49 \mathrm{~g}$ & $8.35 \mathrm{~d}$ & $3.61 \mathrm{~h}$ \\
KGES2 & $1.10 \mathrm{~b}$ & $2.11 \mathrm{ef}$ & $4.57 \mathrm{f}$ & $31.47 \mathrm{~b}$ & $5.98 \mathrm{f}$ & $8.40 \mathrm{~d}$ & $4.15 \mathrm{~g}$ \\
KGES3 & $0.98 \mathrm{c}$ & $2.12 \mathrm{e}$ & $4.76 \mathrm{e}$ & $30.33 \mathrm{c}$ & $7.08 \mathrm{e}$ & $9.33 \mathrm{c}$ & $4.23 \mathrm{f}$ \\
KGES4 & $0.98 \mathrm{c}$ & $2.19 \mathrm{~d}$ & $5.47 \mathrm{~d}$ & $29.46 \mathrm{~d}$ & $7.33 \mathrm{~d}$ & $9.42 \mathrm{c}$ & $4.46 \mathrm{e}$ \\
KGES5 & $0.97 \mathrm{~d}$ & $2.21 \mathrm{~d}$ & $6.27 \mathrm{c}$ & $28.54 \mathrm{e}$ & $8.11 \mathrm{c}$ & $9.78 \mathrm{c}$ & $5.01 \mathrm{~d}$ \\
KGES6 & $0.93 \mathrm{~d}$ & $2.23 \mathrm{c}$ & $6.43 \mathrm{~b}$ & $27.04 \mathrm{f}$ & $8.17 \mathrm{~b}$ & $11.02 \mathrm{~b}$ & $6.52 \mathrm{c}$ \\
KGES7 & $0.80 \mathrm{e}$ & $2.30 \mathrm{a}$ & $7.77 \mathrm{a}$ & $23.54 \mathrm{~h}$ & $8.83 \mathrm{a}$ & $11.62 \mathrm{a}$ & $7.85 \mathrm{a}$ \\
KGES8 & $0.90 \mathrm{~d}$ & $2.25 \mathrm{~b}$ & $6.46 \mathrm{~b}$ & $26.55 \mathrm{~g}$ & $8.20 \mathrm{~b}$ & $11.25 \mathrm{ab}$ & $6.95 \mathrm{~b}$ \\
\hline
\end{tabular}

Description: The numbers followed by the same letter notation in the same column are not significantly different at $5 \%$ level of DMRT.

\section{Soil bulk density $\left({\left.\mathrm{g} . \mathrm{cm}^{-3}\right)}^{-3}\right.$}

Results of analysis of variance of the soil bulk density parameters indicated that the addition of sago pith waste granule compost treatment and inorganic fertilizers had significant effect in decreasing soil bulk density (Table 2). The lowest density of soil bulk was found in the combination treatment Inceptisol with increasing doses of inorganic fertilizer and compost $2 \mathrm{x}$ and sago pith waste granule compost amounted 4 tons $\mathrm{ha}^{-1}$ (KGES8) was equal to $0.80 \mathrm{~g} \mathrm{~cm}^{-3}$ and significantly different from other treatments, whereas highest density of the soil bulk in the control treatment (KGES1) was equal to $1: 20 \mathrm{~g} \mathrm{~cm}^{-3}$ and significantly different from other treatments. The results are consistent with some previous researches that concluded that the addition of compost was able to reduce soil bulk density [14],[23],[30],[31],[32],[33],[34]. The decrease of soil bulk density due to the organic materials contained in the sago pith waste granule compost plays a role in binding soil particles, particles that form a particular pattern. This data similar with De Fretes et al. (1996) findings [35]. This is in line with the opinion by Hillel (1996) which states that the organic material has a bulk density or low density so that the higher the organic materials to the soil giving the soil bulk density will decrease [36]. The addition of compost to the soil increase soil water-holding capacity [37], stimulates biological activity in the soil to break down the soil matric [38], increase soil aggregate stability [32], so that soil bulk density is reduced. The decrease in bulk density is due to the addition of organic materials associated with low particle density in the organic materials; in which when it is combined with the mineral fraction of the soil, it will increase aggregation and the porosity of the soil [29]. Mandal et al. (2013) point out that the decrease rate in bulk density as the result of the addition of organic materials depends on the level of application of compost, the types of the soil, and soil compaction [29].

\section{Soil particle density $\left(\mathrm{g} \mathrm{cm}^{-3}\right)$}

The results of analysis of variance of the soil particle density parameters indicated that the addition of compost treatment sago pith waste granule compost and inorganic fertilizers significantly improves the soil particle density (Table 2). Soil particle density are the lowest in the control treatment (KGES1) was equal to $2.10 \mathrm{~g} \mathrm{~cm}^{-3}$, but not significantly different from KGES2 treatment, while the soil particle density was the highest in the combination treatment $1 / 2 \mathrm{x}$ dose addition of inorganic fertilizer and 12 tons $\mathrm{ha}^{-1}$ sago pith waste granule compost (KGES7) was equal to $2: 30 \mathrm{~g} \mathrm{~cm}^{-3}$ and significantly different from the other treatments. These results are contrast with the results of previous studies which have concluded that the soil bulk density and soil particle density decreased with the addition of 30 and 60 tons $^{-1}$ of manure [32]. Soil particle density is determined by the soil solid particles which tend to be stick to each type of soil, the severity of the solid soil particles is determined by the degree of weathering that require longer periods of time. The addition of organic materials in the form of humus is to improve the soil particle density.

\section{Soil porosity $(\%)$}

The results of analysis of variance on soil porosity parameters indicated that the addition of compost treatment sago pith waste granular compost and inorganic fertilizers had significant effect in the increase of the soil porosity (Table 2). The lowest porosity of the soil was in the control treatment (KGES1) that was equal to $4: 43 \%$ and significantly different from other treatments, while the highest soil porosity was found in the addition of a combination treatment $1 / 2 \mathrm{x}$ dose of inorganic fertilizer and 12 tons $^{-1} \mathrm{a}^{-1}$ sago pith waste granule compost (KGES7) was equal $7.77 \%$ and significantly different from the other treatments. The results are consistent with some previous research results where the addition of manure to the soil may turn out to have real impact on soil porosity [29],[37],[39],[40]. The increase of soil porosity occurs because the organic materials may stimulate the formation of soil aggregates as it is indicated by a decrease in soil bulk density. The increase 
of soil aggregation due to the addition of manure lead to the increase of soil porosity [32], [37], 40]. Mandal et al. (2013) states that the organic material may act as a cementing agent between soil particles that may improve both soil aggregation and porosity [29].

\section{Soil macropore (Ø 30-296 $\mu \mathrm{m})$}

Results of analysis of variance of the soil macropore parameters indicated that the addition of treatment sago pith waste granule compost and inorganic fertilizers had significant effects in the decrease of macropore soil (Table 2). The lowest soil macropore was located on treatments $1 / 2 \times$ dose combination of the addition of inorganic fertilizer and 12 tons ha ${ }^{-1}$ sago pith waste granule compost (KGES7) that is equal to $23: 54 \%$ and significantly different from the other treatments, whereas soil macropore was in the highest for the control treatment (KGES1) was equal tp $33.12 \%$ and significantly different from other treatments. Previous researches have also concluded the same thing where the addition of organic materials in the form of pig manure and the sewage sludge may turn down the soil macropore [41]. However, a previous study concluded that the addition of compost and fertilizer $\mathrm{N}$ in the soil may not significantly affect soil macropore volume [42]. Decaying plant into compost may improve the soil aggregation, porosity, and the amount of soil macropore, all of which may increase the infiltration rate of the soil [43]. The decrease in soil macropore soil aggregation result is indicated by the availability of oxygen, nitrogen, and water vapor needed for root respiration. This is consistent with the notion that the increase in oxygen, carbon dioxide, nitrogen and water vapor along with the increase of soil moisture or porosity. The provision of organic material allows the formation of soil aggregates, which in turn will improve the circulation of air permeability and soil, plant roots may easily penetrate deeper and wider so that the plants become sturdy and are able to absorb plant nutrients better [27]. Silahooy (1999) suggested that, sago pith waste dose administration of 40 tones / ha with different mode of administration can improve soil macropore , micropore and total soil porosity and lower mesopore soil and soil bulk density [44]. The addition of compost to the soil can increase the conductivity of the water. This can be guarantee the availability of a food source for soil organisms that have contributed to the formation of soil macropore [28].

\section{Soil mesopore (}

The results of analysis of variance of the soil parameters mesopore showed that treatment through the provision of sago pith waste granule compost and organic fertilizers had significant increase in mesopore soil (Table 2). The lowest soil mesopore was contained in the control treatment (KGES1) that was equal to 5:49\% and significantly different from the other treatments, while the the highest soil mesopore was in the addition of combination treatment $1 / 2 \times$ dose of inorganic fertilizer and 12 tons ha ${ }^{-1}$ sago pith waste granule compost (KGES7) was equal to $8.83 \%$ and significantly different from other treatments. Previous studies concluded that the addition of organic materials such as manure of pig and sewage sludge may turn down macropore but increase the mesopore [41]. According Widianto et al., (2004), the physical characteristics of top soil layer is very important in soil porosity to support plant growth [45]. The addition of organic materials in the soil may lower the bulk density, improve soil macropore and micropore as well as improve the soil hydraulic conductivity [46]. The increase of soil macropore and mesopore soil due to the addition of compost to the soil may improve soil aggregation and stability which is initiated by some organisms in the soil [47].

\section{Soil micropore (Ø 0.2 - $8.6 \mu \mathrm{m})$}

The results of analysis of variance of the micropore soil parameters showed that the addition of sago pith waste granule compost treatment and inorganic fertilizers significantly affected the increase in micropore soil (Table 2). The lowest soil micropore was in the control treatment (KGES1) (equal to 8.35\%), but not significantly different from KGES2 treatment. The highest micropore soil was found in the addition of a combination treatment $1 / 2 \times$ dose of inorganic fertilizer and 12 tons ha ${ }^{-1}$ sago pith waste granule compost (KGES7) (11.62\%), but not significantly different from KGES8 treatment. The addition of organic materials to the soil may increase the amount of macropore and micropore [43]. The addition of compost may reduce soil bulk density but increase the amount of soil micropore as it is indicated by an increase of soil moisture capacity [48]. The addition of compost to the soil may increase the field capacity [28],[32] and available water holding capacity (AWC at 1.8-4.2 pF). The increase in pore water availability due to the high organic-C sago pith waste granules compost fills the space between macro aggregate, the domain of the crystalline clay, dust and sand fraction to form micro pores, in addition to the role of organic materials in the soil aggregation process.

\section{Height of plants (cm)}

The results of analysis of variance of the parameters of plant height showed that the addition of compost treatment sago pith waste granule compost and inorganic fertilizers significantly affected the increase of plant height (Table 3). The shortest high of the plants were in the control treatment (KGES1) that was equal to 164.59 $\mathrm{cm}$ and not significantly different from the other treatments. The highest height of the plants was in the 
combination treatment $1 / 2 \times$ dose addition of inorganic fertilizer and 12 tons ha ${ }^{-1}$ sago pith waste granule compost (KGES7) amounted at 249.17 and significantly different from the other treatments. This result is consistent with previous studies which concluded that the height of corn crops have a high positive correlation with the addition of cow manure, along with the addition of inorganic fertilizers [10], [49].

Results of analysis of variance of the plant height parameter has not shown any significant influence on the early growth of the corn. The obvious effect of the plant height parameter was shown since 30 days after planting period (Table 3). Previous studies concluded that the use of organic compost in the form of manure may increase corn vegetative growth parameters i.e. plant height, stem diameter, number and leaf area since 4 weeks after application [11].

Table 3 Effect of application of inorganic fertilizers and enriched sago pith waste granule compost on the plant height of corn crops

\begin{tabular}{llllll}
\hline Treatment & \multicolumn{5}{c}{ Average plant height $(\mathrm{cm})$} \\
\cline { 2 - 6 } & $15 \mathrm{HST}$ & $30 \mathrm{HST}$ & $45 \mathrm{HST}$ & $60 \mathrm{HST}$ & $75 \mathrm{HST}$ \\
\hline KGES 1 & 16.42 & $27.32 \mathrm{e}$ & $55.34 \mathrm{~g}$ & $135.21 \mathrm{~g}$ & $164.59 \mathrm{~d}$ \\
KGES 2 & 15.83 & $28.3 \mathrm{~d}$ & $56.72 \mathrm{f}$ & $137.67 \mathrm{f}$ & $202.03 \mathrm{c}$ \\
KGES 3 & 16.74 & $30.08 \mathrm{c}$ & $59.48 \mathrm{e}$ & $140.64 \mathrm{e}$ & $222.62 \mathrm{~b}$ \\
KGES 4 & 16.21 & $30.26 \mathrm{c}$ & $60.75 \mathrm{c}$ & $143.34 \mathrm{~d}$ & $209.13 \mathrm{cb}$ \\
KGES 5 & 15.92 & $30.48 \mathrm{c}$ & $62.08 \mathrm{c}$ & $144.7 \mathrm{c}$ & $222.56 \mathrm{~b}$ \\
KGES 6 & 17.25 & $31.49 \mathrm{~b}$ & $63.43 \mathrm{~b}$ & $145.32 \mathrm{c}$ & $223.48 \mathrm{~b}$ \\
KGES 7 & 17.28 & $32.64 \mathrm{a}$ & $64.64 \mathrm{a}$ & $148.21 \mathrm{a}$ & $249.17 \mathrm{a}$ \\
KGES 8 & 17.95 & $32.07 \mathrm{ab}$ & $63.69 \mathrm{~b}$ & $146.54 \mathrm{~b}$ & $223.91 \mathrm{~b}$ \\
\hline JND 5\% & $\mathrm{T}$ & & &
\end{tabular}

Description: The numbers followed by the same letter notation in the same column are not significantly different at $5 \%$ level of DMRT. $t n=$ not real

In the early stages of plant growth and development, the release and availability of nutrients in inorganic fertilizers is higher. The study showed corn plants with compost treatment (KGES2) at the beginning of the growth seemed slow, but at the later stages, plant height of plants fertilized with inorganic alone or a combination of compost and inorganic had the same height. Arisha et al., (2003) assert the inorganic fertilizers are capable to accelerate the early growth of corn, while organic fertilizers stimulate growth at a later stage. Organic fertilizers enable many species of soil microorganisms that release phytohormones to stimulate plant growth and improve nutrition[50]. The soil organisms also require nitrogen for growth and breeding [51]. But at the end of the visible observation compost alone treatment is not able to keep pace with the growth of plant height compared to inorganic fertilizer alone and a combination of both. Nutrient supply treatment depends on nutrient content of soil and compost was decreased with increases in the need for growth and development of plants.

Laboratory analysis showed a compost made of sago pith waste containing $\mathrm{N}, \mathrm{P}$, and $\mathrm{K}$ is higher than chicken manure, enriched diversification compost in the form of granules increases levels of NPK in a row to $3.9 \%, 1.6 \%$ and $1.9 \%$ compared to compost made of regular garbage, the $\mathrm{C} / \mathrm{N}$ ratio of 10 [52]. Compost that has a $\mathrm{C} / \mathrm{N}$ ratio of 10 means it has a good quality and quickly and decomposes much faster in the provision of plant nutrients. The availability of $\mathrm{P}$ is very important and necessary throughout the life of plants, especially for grain filling in maize. The increase in growth parameters and production of corn on corn crops due KGES7 absorb phosphorus during the growing period. Phosphorus absorption in the vegetative phase encourages vegetative organs perfect, so this is very helpful in the absorption of other elements that are needed in the reproductive phase as $\mathrm{N}$ elements, phosphorus is needed in addition to the reproductive phase of the plants. Besides playing a role in the formation of phosphorus in addition to vegetative organs of plants, phosphorus also plays a role also in increasing the protein content of the fruit or seeds and assist in the production of seeds [54].

\section{Maize dry weight yield (ton ha $\left.{ }^{-1}\right)$}

The results of field experiments showed that sago pith waste granule compost and inorganic fertilizers significantly affects the results of the dry weight of shelled corn (Table 2). The highest results of the dry weight of shelled corn was achieved in the treatment $1 / 2 \times$ dose of inorganic fertilizer + granule compost $12 \mathrm{tha}^{-1}$ (KGES7) amounted to 7.82 tons $\mathrm{ha}^{-1}$. Sago pith waste granule compost may contribute $\mathrm{P}$ to the soil from the decomposition, thus increase of plant height and grains yield. The increase of plant height of corn was followed by an increase in grains yield of dry shelled corn. The existence of a positive correlation between the addition of manure with corn grains yield has also been inferred by some previous studies [10],[37],[49]. The application of compost of cow manure may increase corn grain yield with maximum application limit as much as 18 tons ha ${ }^{-1}$ [11]. The provision of sago pith waste granule compost into the soil will undergo decomposition process that produces organic acids that may reduce the activity of $\mathrm{Al}, \mathrm{Fe}$, and $\mathrm{Mn}$ in acid soils such as Inceptisols. $\mathrm{P}$ is absorbed by the three ions irrespective become available. The process will also affect changes in soil conditions 
(soil $\mathrm{pH}$ increased) so that the roots of the plant will be able to absorb elements of phosphate. Besides the increase of the available-P, it may also be caused by the presence of mineralization of $\mathrm{P}$ in the compost process by microorganisms in the soil [54]. Organic materials are derived from sago pith waste granules compost can also lead to the increase of soil water holding power and reduced soil density. The reduced soil density effects on the ease of plant roots to penetrate the soil so that the roots of wider scope thus increasing the ability of plant roots to absorb nutrients, including P nutrient. Chemical and biological processes in the rhizosphere does not only determine the mobilization and acquisition of soil nutrients and microbial dynamics, but also controls the efficient use of plant nutrients, thus greatly affects crop productivity [54],[56]. In addition, the increase of power of the soil to hold water affects the water content of the soil, thus the increase of the diffusion of phosphate ions from the soil surface to plant roots. Similarly, mainly inorganic P fertilizer together compost sago pith waste granule compost may improve plant $\mathrm{P}$ uptake due to an increase in available $\mathrm{P}$ in the soil. With the increase in available-P in the soil and the roots of the prolonged contact between plant roots and the diffusion of $\mathrm{P}$ present in the soil become larger so that more $\mathrm{P}$ is taken or absorbed by plants. Thus the seed yield of dry shelled corn will increase as well. Seeds formed can be improved by the addition of phosphate after planting. In addition to the increase in plant height and grain yield of corn dried may also be stimulated by the addition of organic fertilizer, as this plant is a plant that responds well to organic fertilizers [2],[52],[54]. Giving compost that contains a lot of organic material is able to provide an optimal environment for the life and activity of soil microorganisms and improve soil physical characteristics such as soil volume weight, grain density, soil porosity, fast pore drainage, slow pore drainage, available pore water and others. While NPK enrichment in compost improves the availability of nutrients faster so easy to form more corn crop dry shelled corn grain yield per plant.

In observation of dry shelled corn grain yield per hectare, the treatment dose differences showed significant differences (Table 2). Application of granule compost alone (KGES2) provides dry shelled corn grain yield $\left(\mathrm{t} \mathrm{ha}^{-1}\right)$ which was equal to the inorganic fertilizer treatment (KGES3). This shows the nutrient content of the enriched compost that may provide crop nutrient needs. Inorganic fertilizer combined with ela sago granule compost may improve the results of 30-47\% compared with either inorganic fertilizer or compost granules alone. Scholars point out that that the combination of compost and inorganic fertilizer gave yields of onion that is more favorable compared with compost alone, although less significantly different from the treatment of inorganic fertilizers alone and is supported by the results of research previously on onion [57]. The combination of inorganic and organic compost may support each other so that during the growth period and lead plants are not experiencing nutrient deficiencies. Inorganic fertilizers will quickly release and provide needed nutrients at the right time, while compost containing high organic materials is capable of repairing the physical, chemical and biological soil that improvement in soil aeration, soil porosity, soil bulk density and the increase of ability to retain water. In terms of aspect of soil chemistry, soil organic materials increases the negative charge that increases the Cation exchange capacity (CEC), while biological organic materials may increase the growth and activity of soil microorganisms. Compost was applied in this study is a diversified compost enriched NPK nutrients, so in addition to functioning as a supplier of soil organic matter also provides nutrients available to plants. Therefore, its application in corn gave higher yields than the inorganic fertilizer alone.

Based on these results, excessive inorganic fertilizer provision that is two times the recommended dosage (KGES2 and KGES8) does not show the result of the increase in dry weight of shelled corn significant (Table 2). The excessive application of inorganic fertilizers does not provide benefits in terms of the effect on growth and yield of corn. Conversely, reduction of half the optimum dose of inorganic fertilizer combined with award of compost granules 8 t.ha $^{-1}$ (KGES5) and 12.7 t. ha $^{-1}$ (KGES7) showed similar results with the same treatment granule compost treatment combined with inorganic optimum dose and twice the optimum dose. The reduction of half the optimum dose of inorganic fertilizer combined with compost granules $8 \mathrm{t}^{\text {. ha }}{ }^{-1}$ (KGES5) and $12.7 \mathrm{t}^{\text {. ha }}{ }^{-1}$ (KGES7) each may improve soil physical characteristics such as the heavy volume of soil, soil density, soil porosity, fast pore drainage, slow pore drainage, available water pores, unavailable pore water and the increase maize productions of $6 \%$ and $32 \%$ compared to inorganic fertilizer alone (KGES3).

The provision compost that contains a lot of organic material is able to provide an optimal environment for the life and activity of soil microorganisms and improve soil physical characteristics such as soil aggregation, soil bulk density, soil particle density, soil porosity and others. The addition of compost to the soil resulted in a decrease of soil bulk density, where it is a positive impact on the increase in porosity of the soil and soil aggregation [28],[29]. Soil porosity has an important role in the formation of soil structure, soil moisture, nutrient enrichment in the soil, and keep the soil microbial diversity, while soil aggregate stability has a positive influence on the process of seed germination, root development and plant shoots [58]. The increased porosity of the soil will increase soil moisture [28] so that the crop water requirement will be fulfilled. This is consistent with previous statements that organic material may increase the water-holding capacity of the soil so that the soil moisture status becomes available for the process of respiration, evaporation and photosynthesis [37]. The decrease in bulk density and increased soil moisture status may increase root growth, making the plant nutrients and the final result [32],[38]. 


\section{CONCLUSION}

Sago pith waste granule compost and inorganic fertilizers significantly affect the physical characteristics of soil including soil bulk density $\left(0.80 \mathrm{~g} \mathrm{~cm}^{-3}\right)$, soil particle density $\left(2.30 \mathrm{~g} \mathrm{~cm}^{-3}\right)$, soil porosity (7.77 \%), soil macropore (23.54 \%), mesopore $(8.83 \%)$, and micropore $(11.62 \%)$. While plant growth (height of the plants) and dry grains of corn production amounted to $249.17 \mathrm{~cm}$ and 7.85 tones ha ${ }^{-1}$. The combination of granule compost and inorganic fertilizer may improve the results of 30-47 \% compared with inorganic fertilizer or granule compost alone. The excessive inorganic fertilizer did not show significant results of the increase of dry shelled corn seeds are. Based on the results of the study, the treatment that gave the highest production of the dry weight of plant height and production of corn was KGES7 i.e. $1 / 2 \mathrm{x}$ dose combination of inorganic fertilizer and 12 tons ha $^{-1}$ sago pith waste granule compost grains. This combination is expected to reduce the use of inorganic fertilizers in order to increase the effectiveness of fertilizer use in the improvement of soil physical characteristics and corn cultivation as well as reduction in Inceptisol.

\section{Acknowledgements}

The author fully acknowledge the completion of this writing is by the love and grace of God Almighty, also supports from various parties, both morally and materially, for it is through this moment the author wishes to express infinite gratitude to: the Rector of the Pattimura University and its faculty members, Rector of the Brawijaya University and its faculty members, the Graduate Program Director and his staff, Dean of the Faculty of Agriculture, University of Pattimura and staffs, Dean of the Faculty of Agriculture, Brawijaya University and staffs, promoter and co-promoter and head of the Laboratory of Chemistry, Soil Physics and Soil Biology, the Faculty of Agriculture, Brawijaya University, Malang and staffs as well as various parties who have contributed during the analysis and writing of this journal. May Allah the Merciful, the Compassionate always bestow His mercy for all the kindness and sincerity given to me as the author.

\section{REFERENCES}

[1] Soemarno, Prinsip-prinsip pengelolaan sumberdaya alam dan lingkungan (Program Pascasarjana Universitas Brawijaya Malang, 2002).

[2] K. Hairiah, Widianto; S.R. Utami, D. Suprayogo, Sunaryo, S.M. Sitompul, B. Lusiana, R. Mulia, M. van Noordwijk, and G. Cadish, Pengelolaan tanah masam secara biologi (International Centre for Research in Agroforestri, Bogor, 2000).

[3] A.N. Susanto dan M.P.Sirappa, Karakteristik dan Ketersediaan Data Sumber Daya Lahan Pulau-Pulau Kecil Untuk Perencanaan Pembangunan Pertanian di Maluku, Jurnal Litbang Pertanian, 26(2), 2007, 41-53.

[4] Syafruddin, M. Rauf, R.Y. Arvan and M. Akil, Requirements for N, P, and K Fertilizers on Inceptisol Haplustepts Soil, Indonesian Journal of Agriculture, 2(1), 2009, 77-84.

[5] I. Celik, I. Ortas, and S. Kilic. Effects of Compost, Mycorrhiza, Manure and Fertilizer on Some Physical Properties of a Chromoxerert Soil, Soil Tillage Res. 78, 2004, 59- 67.

[6] M. Tejada, and J.L. Gonzalez, Application of Different Organic Wastes on Soil Properties and Wheat Yield. Agronomy Journal, 99, 2007,1597-1606.

[7] M. Premsekhar and V.Rajashree, Influence of Organic Manures on Growth, Yield and Quality of Okra, American-Eurasian Journal of Sustainable Agriculture, 3(1), 2009, 6-8.

[8] A. Efthimiadou, D. Bilalis, A. Karkanis and B. Froud-Williams. Combined Organic/Inorganic Fertilization Enhance Soil Quality and Increased Yield, Photosynthesis and Sustainability of Sweet Maize Crop. Australian Journal of Crop Science, 4(9), 2010, 722729.

[9] W. Farhad, M.F. Saleem, M.A. Cheema, H.Z.Khan and H.M. Hammad. Influence of Poultry Manure on the Yield and Quality of Spring Maize, Crop \& Environment, 2(1), 2011, 6-10.

[10] M. Zafar, M.K. Abbasi, A. Khaliq and Z.-ur-Rehman. Effect of Combining Organic Materials With Inorganic Phosphorus Sources on Growth, Yield, Energy Content and Phosphorus Uptake in Maize at Rawalakot Azad Jammu and Kashmir, Pakistan, Archives of Applied Science Research, 3(2), 2011, 199-212.

[11] A.O. Akongwubel, U.B. Ewa, A. Prince, O. Jude, A. Martins, O. Simon and O. Nicholas. Evaluation of Agronomic Performance of Maize (Zea mays L.) under Different Rates of Poultry Manure Application in an Ultisol of Obubra, Cross River State, Nigeria. International Journal of Agriculture and Forestry, 2(4), 2012, 138-144.

[12] A. Efthimiadou, D. Bilalis, A. Karkanis, B. Froud-Williams. Combined Organic/Inorganic Fertilization Enhance Soil Quality and Increased Yield, Photosynthesis and Sustainability of Sweet Maize Crop. Australian Journal of Crop Science, 4(9), 2010, 722-729

[13] A.R. Barzegar, A. Yousefi and A. Daryashenas. The Effect of Addition of Different Amounts and Types of Organic Materials on Soil Physical Properties and Yield of Wheat. Plant Soil, 247, 2002, 295-301.

[14] G. Singh, S.K. Jalota and Y. Singh. Manuring and Residue Management Effects on Physical Properties of a Soil Under the Rice Wheat System in Punjab, India. Soil Till. Res., 94, 2007, 229-238.

[15] J.B. Alfons and A.A. Rivaie. Sagu Mendukung Ketahanan Pangan Dalam Menghadapi Dampak Perubahan Iklim. Perspektif, 10 (2), 2011, 81-91

[16] D.S. Awg-Adeni, S. Abd-Aziz, K. Bujang and M.A.Hassan. Bioconversion of Sago Residue Into Value Added Products. African Journal of Biotechnology, 9(14), 2011. 2016-2021.

[17] M. La Habi, Z. Kusuma dan Widianto. Kajian Cara Pemberian dan Dosis Ela Sagu Terhadap Erosi Tanah, Limpasan Permukaan Serta Pertumbuhan dan Hasil Jagung di Ultisol. MSc. Thesis, University of Brawijaya Malang, 2007.

[18] M.A.A. Kumar, S.K.Gali and N.S. Hebsur. Effect of Different Levels of NPK on Growth and Yield Parameters of Sweet Corn. Karnataka J. Agric. Sci., 20(1), 2007, 41-43.

[19] S.A. Ibrahim and H. Kandil, Growth, Yield and Chemical Constituents of Corn (Zea Maize L.) As Affected by Nitrogen and Phosphors Fertilization under Different Irrigation Intervals. Journal of Applied Sciences Research, 3(10), 2007. 1112-1120.

[20] L.S. Ayeni, E.O.Adeleye and J.O. Adejumo, Comparative Effect of Organic, Organomineral and Mineral Fertilizers on Soil Properties, Nutrient Uptake, Growth and Yield of Maize (Zea Mays). International Research Journal of Agricultural Science and Soil Science, 2(11), 2012, 493-497.

[21] BPS. Statistik Indonesia 2008. Badan Pusat Statistik (BPS), Jakarta, 2009

[22] Badan Pusat Statistik Maluku Utara. Maluku Utara Dalam Angka. Ternate, 2010. 
[23] M.A. Khan, M. Abid, N. Hussain and M.U.Masood, Effect of Phosphorous Levels on Growth and Yield of Maize (Zea mays L.) Cultivars under Saline Conditions. International Journal of Agriculture \& Biology, 7(3), 2005, 511-514.

[24] B. Radjagukguk, Masalah pengapuran tanah mineral masam di Indonesia. Bull:18. Fakultas Pertanian UGM. Yogyakarta, 1983.

[25] P.A. Sanchez, Properties and management of soils in the tropics. John Wiley and Sons, Inc, New York, 1992.

[26] T. Notohadiprawiro, Budidaya Organik: Suatu Sistem Pengusahaan Lahan Bagi Keberhasilan Program Transmigrasi Pola Pertanian Lahan Kering, Ilmu Tanah UGM-Yogyakarta. 2006.

[27] S. Winarso, Kesuburan tanah: Dasar kesehatan dan kualitas tanah. Gaya Media, Yogyakarta, 2005.

[28] D. Fischer, B. Glaser, Synergisms between compost and biochar for sustainable soil amelioration. Management of Organic Waste, 167-198, 2012.

[29] M. Mandal, R.S. Chandran and J.C. Sencindiver, Amending Subsoil with Composted Poultry Litter-I: Effects on Soil Physical and Chemical Properties. Agronomy, 3, 2013, 657-669.

[30] M.R. Bahremand, M. Afyuni, M.A. Hajabbasi and Y. Rezainejad, Short and Mid-Term Effects of Organic Fertilizers on Some Soil Physical Properties. J. Agric. Natur. Resour. Sci. Technol., 6(4), 2003, 125-134.

[31] D.C. Edmeades, The Long-Term Effects of Manures and Fertilizers on Soil Productivity and Quality. Nutr. Cycl. Agroecosyst, 66, $2003,165-180$

[32] A. Rasoulzadeh and A.Yaghoubi, Effect of Cattle Manure on Soil Physical Properties on a Sandy Clay Loam Soil in North-West Iran. Journal of Food, Agriculture \& Environment, 8(2), 2010. 976-979.

[33] G. Civeira, Influence of Municipal Solid Waste Compost on Soil Properties and Plant Reestablishment in Peri-Urban Environments. Chilean Journal of Agricultural Research, 70(3), 2010, 446-453.

[34] M.A. Abbas, S.D.M. Elamin and E.A.M. Elamin, Contribution of Chicken Manure on Soil Chemical and Physical Properties Compared With Urea + Superphosphate Fertilizers, Journal of Science and Technology, 12(4), 2011, 9-16.

[35] P.L. De Fretes, R.W. Zobel and V.A. Sneder, A Method for Studying the Effect of Soil Aggregate Size and Density. Soil. Sci. Soc. Am. J., 60, 1996, 288-290.

[36] D. Hillel, Introduction To Soil Physics. Terjemahan: Pengantar Fisika Tanah. Penerjemah: Susanto.R.H \& R. N. Hamidawati. Mitra Gama Widya, 1996.

[37] H.M.R. Javed, M.S.I. Zamir, A. Tanveer and M. Yaseen, Soil Physical Properties and Spring Maize Yield as Influenced by Different Tillage Practices and Integrated Use of Poultry Manure With Synthetic Fertilizers, J. Agric. Res., 51(3), 2013, 277-287.

[38] D.I. Akanni, S.O. Ojeniyi and M.A. Awodun, Soil Properties, Growth Yield and Nutrient Content of Maize, Pepper and Amaranthus as Influenced by Organic and Organomineral Fertilizer, Journal of Agricultural Science and Technology, 4(1), 2011, 1074-1078.

[39] T.M. Agbede, S.O, Ojeniyi and A.J. Adeyemo. Effect of Poultry Manure on Soil Physical and Chemical Properties, Growth and Grain Yield of Sorghum in Southwest, Nigeria, Am.-Eurasian J. Sustain. Agric., 2(1), 2008.72-77.

[40] J.E. Okon, E.O. Mbong, G.J. Ebukanson and O.H. Uneh, Influence of Nutrient Amendments of Soil Quality on Germination, Growth and Yield Components of Two Varieties of Okra (Abelmoschus esculentus (L.) Moench) Sown at University of Uyo Botanical Garden, Uyo, Akwa Ibom State. E3 Journal of Environmental Research and Management, 4(3), 2013, 0209-0213.

[41] T. Głąb and K. Gondek, Effect of Organic Amendments on Morphometric Properties of Macropores in Stagnic Gleysol Soil, Polish J. of Environ. Stud., 17(2), 2008. 209-214.

[42] T. Głąb, T. Zaleski, E. Erhart and W. Hart, Effect of Biowaste Compost and Nitrogen Fertilization on Macroporosity and Biopores of Molli-gleyic Fluvisol Soil, Int. Agrophysics, 22, 2008, 303-311.

[43] FAO (Food and Agriculture Organization). The Importance of Soil Organic Matter, Key to Drought-Resistant Soil and Suistained Food and Production. FAO Soil Bulletin no. 80. Rome. 2005.

[44] C.H. Silahooy, Beberapa Sifat Fisik Tanah, Kehilangan Air Oleh Aliran Permukaan, dan Vertikal, Erosi Tanah, dan Hasil Jagung (Zea mays. L) Pada Tipic Paleudults yang Diberi Ela Sagu Beberapa Dosis dan Cara Pemberiannya. MSc. Tesis Fakultas Pertanian Universitas Padjadjaran Bandung, 1999.

[45] Widianto, H. Noveras, D. Suprayogo, P. Purnomosidhi, M.Van Noordwijk, Konversi Hutan Menjadi Lahan Pertanian: “Apakah Fungsi Hidrologis Hutan Dapat Digantikan Agroforestri Berbasis Kopi”, Agrivita, 26(1), 2004, 47-52.

[46] C.S. Wortmann and C.A. Shapiro, The Effects of Manure Application on Soil Aggregation. Nutr Cycl Agroecosyst, 80, 2007, 173180.

[47] B. Liu, M.L. Gumpertz, S. Hu and J.B.Ristaino, Long-Term Effects of Organic and Synthetic Soil Fertility Amendments on Soil Microbial Communities and the Development of Southern Blight, Soil Biology and Biochemistry, 39, 2007, 2302-2316.

[48] A.M. Thompson, A.C. Paul, N.J. Balster, Physical and Hydraulic Properties of Engineered Soil Media for Bioretention Basins, Transaction of the ASABE, 51(2), 2008, 499-514.

[49] S. Adamu and B.O. Leye, Performance of Maize (Zea mays L.) as Influenced by Complementary Use of Organic and Inorganic Fertilizers. International Journal of Science and Nature, 3(4), 2012,753-757.

[50] H.M.E. Arisha, A.A. Gad and S.E. Younes, Response of Some Pepper Cultivars to Organic and Mineral Nitrogen Fertilizer Under Sandy Soil Conditions, Zagazig Journal Agriculture Research, 30, 2003, 1875-1899.

[51] B.A. Ouda and A.Y. Mahadeen, Effect of Fertilizers on Growth, Yield, Yield Components, Quality and Certain Nutriet Contents in Broccoli (Brassica oleraceae). International Journal of Agriculture and Biology, 10(6), 2008. 627-632.

[52] La Habi, M., Z. Kusuma, S. Prijono, B. Prasetyo. Ketersediaan Fosfat, Serapan Fosfat dan Hasil Tanaman Jagung Akibat Pemberian Pupuk Organik Granul Ela Sagu Dengan Pupuk Fosfat Pada Inceptisol. Plumula; Berkala Ilmiah Agroteknologi, 1(2), 2012. 144-155.

[53] Hardjowigeno, S. Ilmu Tanah. Penerbit Akademika Pressindo-Jakarta, 2003.

[54] S. Minardi, S. Suntoro, Syekhfani, E. Handayanto. Penggunaan Macam Bahan Organik dengan Kandungan Total Asam Humat dan Asam Fulvat Berbeda dan Pupuk P Terhadap Ketersediaan dan Serapan P Pada Tanaman Jagung Manis. Agrivita, 29, 2007, 131137.

[55] P. Hinsinger, A.G. Bengough, D. Vetterlein, I.M. Young. Rhizosphere: Biophysics, Biogeochemistry, and Ecological Relevance. Plant Soil, 321, 2009, 117-152.

[56] F. Zhang, J. Shen, J. Zhang, Y. Zuo, L. Li, X. Chen. Rhizosphere Processes and Management for Improving Nutrient Use Efficiency and Crop Productivity: Implications for China. Adv. Agron., 107, 2010, 1-32.

[57] L. Abbey, R.A.L. Kanton. Fertilizer Type, But Not Time of Cessation Of Irrigation, Affect Onion Development and Yield in a Semi Arid Region. Journal of Vegetable Crop Production, 9(2), 2004, 41-48.

[58] J.T. Li, X.L.Zhong, F. Wang, Q.G. Zhao. Effect of Poultry Litter and Livestock Manure on Soil Physical and Biological Indicators in a Rice-Wheat Rotation System. Plant Soil Environ., 57(8), 2011, 351-356. 